\title{
An Investigation About the Factors Influence on the Wavelength Dispersive X-Ray Fluorescence Spectrometer Measurement Results*
}

\author{
Nuray ÜST ${ }^{1}$, Burcu AKÇA², Salih Zeki ERZENEOĞLU ${ }^{1}$
}

\begin{abstract}
In this study, in the product waste after treatment of boron the different masses, cellulose ratios and different scanning surface areas effect on analysis results and the effect of press pressing on the analysis results in the potassium nitrate (KNO3) samples were investigated. The aim of our work is determined the different masses, cellulose ratios, press pressing, and different scanning surface areas effect on the analysis results by using the Wavelength Differential X-Ray Fluorescence Spectrometer (WDXRFS).
\end{abstract}

Keywords:Analysis, boron, wavelength dispersive x-ray fluorescence spectrometer.

\section{Dalgaboyu Ayrımlı X-Işını Floresans Spektrometre Ölçüm Sonuçları Üzerine Etki Eden Faktörler Hakkında Bir İnceleme}

ÖZET: Bu çalışmada borun işlenmesinden sonraki ürün atığında, farklı kütleler, selüloz oranları ve farklı tarama yüzey alanlarının analiz sonuçları üzerine etkisi ve potasyum nitrat $\left(\mathrm{KNO}_{3}\right)$ numunesinde pres basıncının analiz sonuçlarına etkisi incelenmiştir. Çalışmamamızın amacı farklı kütleler, selüloz oranları, pres basıncı ve farklı tarama yüzey alanlarının analiz sonuçları üzerine etkisini Dalgaboyu Ayrımlı X-Işını Floresans Spektrometre (WDXRFS) kullanarak belirlemektir.

Anahtar Kelimeler:Analiz, bor, dalgaboyu ayrımlı x-ışını floresans spektrometre.

Nuray ÜST (0000-0003-0760-5195), Salih Zeki ERZENEOĞLU (0000-0002-0890-6099), Atatürk University, Faculty of Sciences, Department of Physics, Erzurum, Turkey

Burcu AKÇA (0000-0003-2399-5971), Ardahan University, Faculty of Engineering, Computer Engineering, Ardahan, Turkey Sorumlu yazar/Corresponding Author: Burcu AKÇA, burcuakca@ardahan.edu.tr

Bu çalışma Nuray ÜST'ün Yüksek Lisans tezinin bir bölümüdür. 


\section{INTRODUCTION}

Investigation of severities of X-ray lines for different elements is an important task in atomic, molecular and radiation physics, geological and medical research, the qualitative and quantitative analysis in other fields. So, It is necessary the accurate measurements of these lines. Factors that influence measurements such as the sample preparation process, the effect of the counting system and environmental conditions are important. The sample preparation process is an important step in the chemical analysis process. The sample preparation process is an important step in the chemical analysis process. Analysis of atomic spectroscopic procedures practically always necessitates a simple or more complex preparation process of the samples. This step is the most critical part of the analysis due to an error in this step affects all measurement results (Hoening and Kersabiac, 1996; Cal-Prieta et al., 2002; Oliveira, 2003). However, if one examines the literature one often finds that details on how a sample was prepared are often omitted for most analytical methods of analysis (Buhrke, 1998).

In the literature, a variety of experimental data relevant to the qualitative and quantitative analysis of different samples available. Multielement analyses of plants have been studied by using WDXRFS. However, the multi-element composition of plant samples has been analyzed by using x-ray fluorescence spectrometry (Garivait et al., 1997). A simple and cheap procedure has been described for simultaneous determination of $\mathrm{V}, \mathrm{Cr}$, $\mathrm{Mn}, \mathrm{Fe}, \mathrm{Co}, \mathrm{Ni}, \mathrm{Cu}$ and $\mathrm{Zn}$ contents in water by means of WDXRFS after preconcentration (Yamini et al., 2009). A comparative study on the elemental composition of various hazelnut (Corylus avellana L.) samples has been conducted by using a sensitive procedure, WDXRF (Akbaba et al. 2011). A method has been developed for quantitative measurement of the elemental composition of particulate matter (PM) in seawater. This procedure is based on the use of WDXRF analyzing PM harvested on various filter types (Paulino et al., 2013). Concentrations of trace mineral nutrients such as $\mathrm{Cu}, \mathrm{Fe}$, and $\mathrm{Zn}$ have been analyzed by WDXRF in eight different infant milk powders (Fernandes et al., 2015). Elemental analysis of different soil and geological samples have been determined by using WDXRF (Kubala et al., 2015). WDXRF has been used for quantitative and qualitative analysis of the elemental composition of cosmetic products (McWilliams et al., 2015). Enamel and dentine in human, bovine, porcine and ovine teeth have been determined by using WDXRF. The chemical compositions of these samples have been compared by using WDXRF technique (Teruel et al., 2015). The rare earth elements in combustion ashes from selected Polish coal mines have been determined by using WDXRFS (Smolinski et al., 2016). It is seen that there are few studies on the factors affecting the WDXRF measurement results in the literature review. The goal of this work completes this deficiency of the literature and other studies create basis.

\section{MATERIAL AND METHOD}

\section{Preparation of sample}

Firstly, samples milled to ensure homogeneity about $10 \mathrm{~min}$. After, these samples are mixed at $2 \mathrm{~min}$ by SPEX mixer. The powder samples were compressed using 7-10 tons pressure manual hydraulic press. The pellets were prepared for product waste after treatment of boron (100, 150, 200, 250, 300, and $350 \mathrm{mg}$ mass) and $\mathrm{KNO}_{3}(150,200,250,300,350,400$, and 450 $\mathrm{mg}$ mass). However, product waste after treatment of boron (200 mg mass) was added different ratios of cellulose.

\section{Wavelength dispersive $x$-ray fluorescence spectrometer}

The element concentrations were detected by using WDXRFS of ZSX 1000 of Rigaku firm. Elements, in a wide range, from $\mathrm{Be}$ to $\mathrm{U}$, can be analyzed in a variety of sample types and in the concentration range from $100 \%$ down to the subppm-level. This system has the ability to analyze the energy range $0.1-5.9 \mathrm{keV}$. Additionally, it is the counting time $10-4000 \mathrm{~s}$, counting rate $5 \times 10^{3} \mathrm{~s}^{-1}$ and the detection limits in 1000 second around (ng, $\mathrm{mg}^{-1}$ ). The schematically arrangement of the WDXRFS used in this study is shown in Figure 1. 


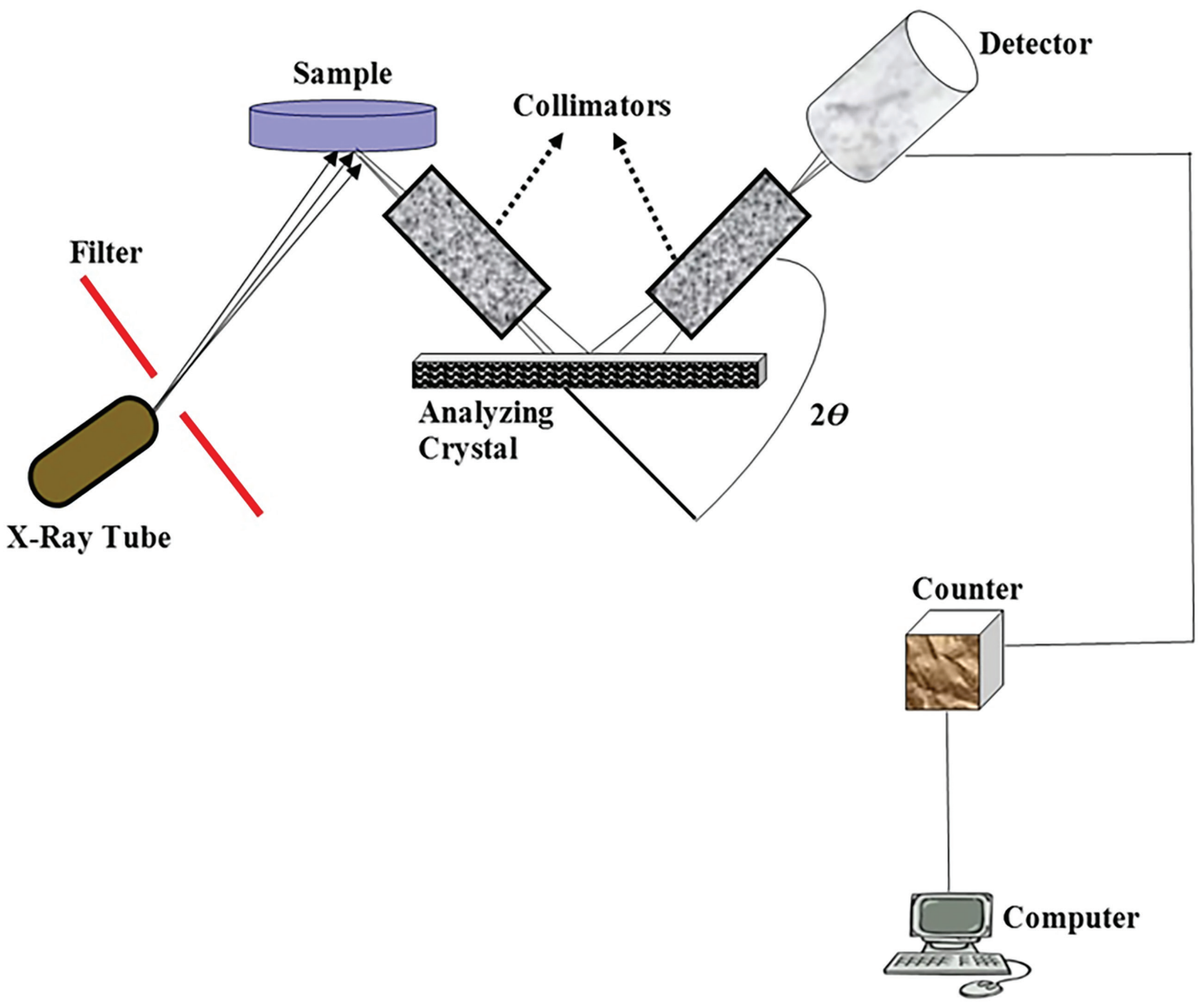

Figure 1. The schematically arrangement of the WDXRFS

\section{RESULTS AND DISCUSSION}

In present work, we examined the factors such as pressure, mass, the ratio cellulose, scanning surface areas and press pressing for two samples that influence on element concentration and measurement results with WDXRFS. Results of measurement are given with tables. Firstly, the effect of some factors were examined for product waste after treatment of boron. The effect on elements concentrations of cellulose ratio $(0 \%$, $1 \%, 2 \%$, and $4 \%$ ) are given Table 1 for product waste after treatment of boron (200 mg mass). 
Nuray ÜST et al.

Table 1. The concentration of elements $\left(\mu \mathrm{g} / \mathrm{cm}^{2}\right)$ for product waste after treatment of boron $(200 \mathrm{mg})$

\begin{tabular}{ccccc}
\hline & $0 \%$ & $1 \%$ & $2 \%$ & $4 \%$ \\
\hline Elements & \multicolumn{4}{c}{ concentr ation of elements } \\
\hline $\mathrm{C}$ & - & - & - & 27.1034 \\
$\mathrm{O}$ & - & - & - & 54.4528 \\
$\mathrm{Na}$ & 0.2413 & 0.2018 & 0.2382 & 0.0593 \\
$\mathrm{Mg}$ & 4.3217 & 4.2056 & 4.3739 & 1.0925 \\
$\mathrm{Al}$ & 22.0294 & 22.0998 & 22.1337 & 5.1824 \\
$\mathrm{Si}$ & 55.6585 & 56.0096 & 55.6860 & 10.2001 \\
$\mathrm{P}$ & 0.2630 & 0.2530 & 0.2570 & 0.0362 \\
$\mathrm{~S}$ & 0.6809 & 0.5723 & 0.5810 & 0.0733 \\
$\mathrm{Cl}$ & 0.0236 & 0.0453 & - & - \\
$\mathrm{K}$ & 3.7291 & 3.6841 & 3.6062 & 0.4459 \\
$\mathrm{Ca}$ & 3.9753 & 3.8197 & 3.8583 & 0.4626 \\
$\mathrm{Ti}$ & 0.7079 & 0.6721 & 0.6972 & 0.0795 \\
$\mathrm{Cr}$ & 0.0896 & 0.1099 & 0.1112 & 0.0110 \\
$\mathrm{Mn}$ & 0.1128 & 0.1075 & 0.2431 & 0.0090 \\
$\mathrm{Fe}$ & 7.9132 & 7.9258 & 7.9823 & 0.7688 \\
$\mathrm{Ni}$ & 0.1838 & 0.1696 & 0.1636 & 0.0149 \\
$\mathrm{Cu}$ & - & 0.0114 & - & 0.0011 \\
$\mathrm{Zn}$ & 0.0180 & 0.0154 & 0.0109 & 0.0014 \\
$\mathrm{As}$ & 0.0122 & - & 0.0114 & 0.0010 \\
$\mathrm{Rb}$ & 0.0098 & 0.0078 & 0.0084 & 0.0008 \\
$\mathrm{Sr}$ & 0.0274 & 0.0245 & 0.0248 & 0.0022 \\
$\mathrm{Zr}$ & 0.0124 & 0.0138 & 0.0128 & 0.0020 \\
$\mathrm{~Pb}$ & - & 0.0508 & 1.0201 & - \\
$\mathrm{C} 6 \mathrm{H} 10 \mathrm{O} 5$ & 1.0115 & & \\
& 0.0205 & & & \\
\hline
\end{tabular}

Table 1. it is clearly seen that the concentrations of elements remarkable change was not observed in $0 \%$, $1 \%$, and $\% 2$ cellulose ratios. Contrary to it, generally, concentrations of elements decreased for $4 \%$ cellulose ratio. However, the concentrations of elements are different in $0 \%$ cellulose ratio. This difference is not most remarkable but most important. The cellulose is enough to be able to pellet the sample. If it is obligatory to added cellulose in the sample, several measurements should be taken at different cellulose rates. The effect on elements concentration of sample mass is listed Table 2 for product waste after treatment of boron (100, $150,200,250,300$, and $350 \mathrm{mg}$ mass). 
Table 2. The concentration of elements $\left(\mu \mathrm{g} / \mathrm{cm}^{2}\right)$ for product waste after treatment of boron

\begin{tabular}{ccccccc}
\hline & $100 \mathrm{mg}$ & $150 \mathrm{mg}$ & $200 \mathrm{mg}$ & $250 \mathrm{mg}$ & $300 \mathrm{mg}$ & $350 \mathrm{mg}$ \\
\hline Elements & \multicolumn{7}{c}{ concentr ation of elements } \\
\hline $\mathrm{B}$ & 6.2957 & 5.7523 & 6.7252 & 5.6109 & 5.5878 & 5.2678 \\
$\mathrm{C}$ & 7.4472 & 7.3033 & 7.9632 & 6.5790 & 6.8678 & 6.5742 \\
$\mathrm{O}$ & 51.5784 & 52.7228 & 54.9034 & 53.2170 & 52.3066 & 52.4457 \\
$\mathrm{Na}$ & 0.0875 & 0.1138 & 0.1432 & 0.0810 & 0.1749 & 0.1060 \\
$\mathrm{Mg}$ & 3.5934 & 3.6945 & 3.4375 & 3.6489 & 3.7002 & 3.9557 \\
$\mathrm{Al}$ & 2.2990 & 2.0833 & 1.8632 & 1.9738 & 2.0312 & 2.1246 \\
$\mathrm{Si}$ & 7.8315 & 7.8214 & 7.1094 & 7.9187 & 7.9647 & 8.2221 \\
$\mathrm{P}$ & 0.0360 & 0.0348 & 0.0333 & 0.0370 & 0.0352 & 0.0355 \\
$\mathrm{~S}$ & 0.3412 & 0.3395 & 0.3079 & 0.3413 & 0.4364 & 0.3489 \\
$\mathrm{~K}$ & 0.8101 & 0.8059 & 0.7115 & 0.8163 & 0.8439 & 0.8256 \\
$\mathrm{Ca}$ & 18.8992 & 18.7513 & 16.1401 & 18.9541 & 19.2106 & 19.2513 \\
$\mathrm{Ti}$ & 0.0755 & 0.0774 & 0.0532 & 0.0514 & 0.0533 & 0.0599 \\
$\mathrm{Mn}$ & 0.0257 & 0.0151 & 0.0174 & 0.0274 & 0.0249 & 0.0230 \\
$\mathrm{Fe}$ & 0.5459 & 0.3363 & 0.0455 & 0.5774 & 0.6033 & 0.6091 \\
$\mathrm{Ni}$ & 0.0049 & 0.0072 & - & 0.0063 & 0.0054 & - \\
$\mathrm{Zn}$ & - & - & 0.0144 & - & - & - \\
$\mathrm{As}$ & 0.0044 & 0.0058 & 0.0036 & 0.0057 & 0.0062 & 0.0043 \\
$\mathrm{Rb}$ & 0.0026 & 0.0035 & 0.0030 & 0.0033 & 0.0052 & 0.0036 \\
$\mathrm{Sr}$ & 0.1082 & 0.1187 & 0.1027 & 0.1339 & 0.0032 & 0.1427 \\
$\mathrm{Pd}$ & 0.0135 & - & 0.0124 & 0.0167 & 0.1393 & - \\
\hline
\end{tabular}

As seen in Table 2, in the concentrations of elements remarkable change was not observed for product waste after treatment of boron $(100,150,200,250,300$, and $350 \mathrm{mg}$ mass). The reason is that during the WDXRFS measurements often the of the surface of the samples are scanned. Besides it was observed that the samples with 100 and $150 \mathrm{mg}$ masses had surface cracking and color change during the analysis. The effect on element concentrations of scanning the surface area of the sample $(3 \mathrm{~mm}, 10 \mathrm{~mm}$, and mylar-coated $10 \mathrm{~mm}$ sample diameter) shown in Table 3 for product waste after treatment of boron (100 mg mass).

In this section, $13 \mathrm{~mm}$ diameter tablet samples were prepared and $3 \mathrm{~mm}$ and $10 \mathrm{~mm}$ diameter scanning surface were selected from the measuring system for these samples. 
Nuray ÜST et al.

Table 3. The concentration of elements $\left(\mu \mathrm{g} / \mathrm{cm}^{2}\right)$ for different scanning the surface area of product waste after boron treatment

\begin{tabular}{cccc}
\hline & 3 mm diameter & 10 mm diameter & 10 mm diameter (mylar-coated) \\
\hline Elements & & concentr ation of elements & - \\
\hline $\mathrm{B}$ & 6.8301 & 7.9688 & 58.3642 \\
$\mathrm{C}$ & 6.5684 & 8.2438 & 30.6848 \\
$\mathrm{O}$ & 54.1133 & 52.7855 & - \\
$\mathrm{Na}$ & - & 0.0993 & 0.3405 \\
$\mathrm{Mg}$ & 3.3018 & 3.5506 & 0.3846 \\
$\mathrm{Al}$ & 1.8532 & 1.9959 & 1.9278 \\
$\mathrm{Si}$ & 7.4678 & 7.3057 & 0.0115 \\
$\mathrm{P}$ & 0.0256 & 0.0314 & 0.1033 \\
$\mathrm{~S}$ & 0.2875 & 0.2931 & 0.3250 \\
$\mathrm{~K}$ & 0.7709 & 0.7224 & 7.5675 \\
$\mathrm{Ca}$ & 17.9751 & 16.3551 & 0.0191 \\
$\mathrm{Ti}$ & - & 0.0620 & 0.0072 \\
$\mathrm{Mn}$ & 0.0269 & 0.0172 & 0.2157 \\
$\mathrm{Fe}$ & 0.6503 & 0.4677 & 0.0018 \\
$\mathrm{Ni}$ & 0.0081 & 0.0056 & 0.0011 \\
$\mathrm{As}$ & 0.0064 & 0.0033 & 0.0413 \\
$\mathrm{Sr}$ & 0.1044 & 0.0843 & 0.0048 \\
$\mathrm{Pd}$ & 0.0102 & 0.0085 &
\end{tabular}

It is observed from Table 3, generally, that concentrations of element decreased to $10 \mathrm{~mm}$ diameter (mylar-coated). The concentrations of elements remarkable change weren't observed for $3 \mathrm{~mm}$ and 10 mm diameter.
Secondly, the effect of press pressure is examined for $\mathrm{KNO}_{3}$. The effect on element concentrations of 7-ton press pressure and 10-ton press pressure is listed Table 4 and 5 for $\mathrm{KNO}_{3}(13 \mathrm{~mm}$ diameter, 100, 150, 200, 250, $300,350,400$, and $450 \mathrm{mg}$ mass).

Table 4. The concentration of elements $\left(\mu \mathrm{g} / \mathrm{cm}^{2}\right)$ for 7-ton press pressure applied to $\mathrm{KNO}_{3}$

\begin{tabular}{cccccccc}
\hline & $150 \mathrm{mg}$ & $200 \mathrm{mg}$ & $250 \mathrm{mg}$ & $300 \mathrm{mg}$ & $350 \mathrm{mg}$ & $400 \mathrm{mg}$ & $450 \mathrm{mg}$ \\
\hline Elements & \multicolumn{7}{c}{ concentr ation of elements } \\
\hline $\mathrm{B}$ & - & - & - & - & 1.7866 & - & - \\
$\mathrm{N}$ & 11.7812 & 10.7023 & 10.9700 & 12.9230 & 11.1117 & 9.9762 & - \\
$\mathrm{O}$ & 41.5156 & 42.0656 & 42.3220 & 42.1239 & 42.3418 & 42.6402 & 42.5300 \\
$\mathrm{Na}$ & 0.1512 & 0.1437 & 0.1229 & 0.0784 & 0.0631 & 0.1156 & 0.1085 \\
$\mathrm{Si}$ & - & 0.0167 & - & - & - & - & - \\
$\mathrm{P}$ & - & - & 0.0020 & - & - & - & - \\
$\mathrm{S}$ & - & 0.0046 & - & - & - & - & - \\
$\mathrm{K}$ & 46.5319 & 47.0670 & 46.5607 & 44.8533 & 44.6968 & 47.2174 & 57.3274 \\
$\mathrm{Pd}$ & 0.0200 & - & 0.0223 & 0.0214 & - & 0.0284 & 0.0341 \\
\hline
\end{tabular}


Table 5. The concentration of elements $\left(\mu \mathrm{g} / \mathrm{cm}^{2}\right)$ for 10-ton press pressure applied to $\mathrm{KNO}_{3}$

\begin{tabular}{cccccccc}
\hline & $150 \mathrm{mg}$ & $200 \mathrm{mg}$ & $250 \mathrm{mg}$ & $300 \mathrm{mg}$ & $350 \mathrm{mg}$ & $400 \mathrm{mg}$ & $450 \mathrm{mg}$ \\
\hline Elements & \multicolumn{7}{c}{ concentr ation of elements } \\
\hline $\mathrm{B}$ & - & - & - & - & 0.7396 & - & - \\
$\mathrm{N}$ & - & 8.1262 & 8.0281 & - & 6.6912 & - & 7.0903 \\
$\mathrm{O}$ & 27.9042 & 27.7428 & 28.8248 & 30.4128 & 28.7657 & 29.0299 & 27.6109 \\
$\mathrm{Na}$ & 0.1179 & 0.1120 & 0.1199 & 0.0709 & 0.0757 & 0.1218 & 0.1580 \\
$\mathrm{Mg}$ & 0.0232 & 0.0174 & - & 0.0175 & - & - & - \\
$\mathrm{Al}$ & 0.0101 & - & 0.0081 & - & - & - & - \\
$\mathrm{Si}$ & 0.0301 & 0.0190 & 0.0230 & 0.0189 & - & - & - \\
$\mathrm{S}$ & 0.0044 & 0.0050 & 0.0030 & - & - & - & 0.0027 \\
$\mathrm{Cl}$ & - & 0.0205 & - & 0.0181 & - & - & - \\
$\mathrm{K}$ & 71.9101 & 63.9572 & 61.9222 & 68.1632 & 62.6672 & 69.3746 & 64.1925 \\
$\mathrm{Cu}$ & - & - & - & - & - & 0.0362 & - \\
$\mathrm{Pd}$ & - & - & 1.0709 & 1.2691 & 1.0616 & 1.4375 & 0.9457 \\
\hline
\end{tabular}

In Tables 4. and 5, the concentrations of element significant change was observed. The elemental concentrations have a relative change of 7 and 10 tons' pressure. Also, when pressure increases from 7 to 10 tons, generally, the $\mathrm{Z}>11$ increased concentrations

\section{CONCLUSIONS}

As a result, the sample preparation process is an important step in qualitatively and quantitatively analyzed. The experiments and measurements depend mainly upon the mass of the sample, applied pressure, the ratio of cellulose, the effect of scanning the surface area of the sample, instrument operation conditions and the environmental conditions. So, these conditions

\section{REFERENCES}

Akbaba U, Şahin Y, Turkez H, 2011. Element content analysis by WDXRF in pistachios grown under organic and conventional farming regimes for human nutrition and healthy. Fresenius Environmental Bulletin, 20: 1655-1660.

Buhrke, V. E., 1998, Specimen Preparation. Rigaku Journal, 16: 3-5.

Cal-Prieto M.J, Felipe-Sotelo, M, Carlosena, A., Andrade, J.M, López-Mahía, P, Muniategui, S, Prada, D, 2002, Slurry sampling for direct analysis of solid materials by electrothermal atomic absorption spectrometry (ETAAS): A literature review from 1990 to 2000. Talanta, 56: 1-51. of elements and $\mathrm{Z} \leq 11$ decreased concentrations of elements. These results demonstrate the importance of the applied pressure and sample thickness when preparing the sample.

should be taken into account in order to good experimental results.

These conditions should be taken into account for future experimental studies. In the future, this work repeatable for EDXRF (Energy Dispersive X-Ray Fluorescence) or different measurement systems, different samples, different energies, and different experimental factors.

Fernandes, T A P, Brito, J A A, Goncalves, L M L, 2015, Analysis of Micronutrients and Heavy Metals in Portuguese Infant Milk Powders by WDXRF. Food Analytical Methods, 8: 52-57.

Garivait, S, Quisefit, J.P, Chateaubourg, P, Malingre, G, 1997, Multi-Element Analysis of Plants by WDXRF using Scattered Radiation Correction Method. X-Ray Spectrometry, 26: 257264.

Hoenig, M, Kersabiec, A.M, 1996, Sample preparation steps for analysis by atomic spectroscopy methods: present status. Spectrochimica Acta Part B: Atomic Spectroscopy, 51, 12971307. 
Kubala-Kukus, A, Banas, D, Braziewicz, J, Dziadowicz, M, Kopec, E, Majewska, U, Mazurek, M, Pajek, M, Sobisz, M, Stabrawa, I, 2015, X-ray spectrometry and X-ray microtomography techniques for soil and geological samples analysis. Nuclear Instruments \& Methods in Physics Research Section B-Beam Interactions with Materials and Atoms, 364: 85-92.

McWilliams, A.C, Martin, A. A, Levine, M. A, Levine, K. E, Felder, L, Young, D. J, Harrington, J. M, 2015, Preparation of Thin Films for Elemental Analysis of Nail Polish by WDXRFS. Analytical Letters, 48: 2122-2135.

Oliveira, E, 2003. Sample preparation for atomic spectroscopy: evolution and future trends. Journal of the Brazilian Chemical Society, $14,174-182$

Paulino, A.I; Heldal, M, Norland, S, Egge, J.K, 2013, Elemental stoichiometry of marine particulate matter measured WDXRFS. Journal of the Marine Biological Association of the United Kingdom, 93:2003-2014.
Smolinski, A, Stempin, M, Howaniec, N, 2016, Determination of rare earth elements in combustion ashes from selected Polish coal mines by WDXRFS. Spectrochimica Acta Part B-Atomic Spectroscopy, 116: 63-74.

Teruel, J.D, Alcolea, A, Hernandez, A, Ruiz, A.J.O, 2015, Comparison of chemical composition of enamel and dentine in human, bovine, porcine and ovine teeth. Archives of Oral Biology, 60: 768-775.

Yamini, Y, Amiri, N, Karimi, M, 2009, Determination of trace elements in natural water using $\mathrm{X}$-ray fluorescence spectrometry after preconcentration with powdered silica gel. X-Ray Spectrom., 38: 474-478. 